\title{
Analysis Of Financial Of A Durian (Durio Zibethinus Murr) Nursery Bussines
}

\author{
Analisis Finansial Usaha Pembibitan Durian \\ (Durio Zibethinus Murr)
}

\author{
Nursamsi \\ Program Studi Agribisnis Fakultas Pertanian \\ Universitas Muhammadiyah Sumatera Utara \\ email : nursamsi@umsu.ac.id
}

\begin{abstract}
ABSTRACK
This study aims to determine how much income and financial viability of a durian nursery business located in Tanjung Morawa, Deli Serdang. Method of location determination is done by purposive (intentional) is the consideration that area are carefully selected to match the expected conditions. Methods of sampling done by the Census methods namely in choosing the sample by taking all members of the population. This study aims to determine how the level of income, feasibility and effort to overcome the problems in breeding durian. The results showed that the average farm income durian seedlings Rp. 40.3125 million. Feasibility with a value of $R / C 2.3>1$ and the $B / C 1.3>1$ then the business is said to be worth the effort.
\end{abstract}

Keywords: Financial, Durian, Revenue

Penelitian ini bertujuan adalah untuk mengetahui seberapa besar pendapatan serta kelayakan finansial dari suatu usaha pembibitan durian yang terletak di Tanjung Morawa, Deli Serdang. Metode penentuan lokasi dilakukan dengan cara purposive (sengaja) yaitu dengan pertimbangan bahwa daerah dipilih secara cermat agar sesuai dengan kondisi yang diharapkan. Metode penentuan sampel dilakukan dengan metode secara Sensus yaitu dalam memilih sampel dengan mengambil semua anggota populasi. Penelitian ini bertujuan untuk mengetahui bagaimana tingkat pendapatan, kelayakan usaha dan upaya mengatasi masalah dalam pembibitan durian. Hasil penelitian menunjukkan bahwa rata-rata pendapatan usahatani pembibitan durian sebesar Rp. 40.312.500. Kelayakan usaha dengan nilai R/C 2,3 >1 dan nilai B/C 1,3>1 maka usaha dikatakan layak untuk diusahakan

Kata kunci: Finansial, Durian, Pendapatan

\section{A. PENDAHULUAN}

Pembangunan di bidang pertanian diarahkan untuk meningkatkan pendapatan dan taraf hidup petani. Memperluas lapangan pekerjaan dan kesempatan usaha. Memperluas pasar, baik pasar dalam negeri maupun pasar luar negeri. Melalui pertanian maju, efisien dan tangguh, sehingga mampu meningkatkan kualitas serta menunjang pembangunan wilayah.

Sektor pertanian merupakan sektor yang menyerap tenaga kerja yang cukup besar, sebagai penyedia bahan makanan dan sangat bermanfaat bagi konsumen sektor lain baik industri maupun jasa. Oleh karena itu arah pembangunan pertanian di masa mendatang tetap ditekankan pada peningkatan kesejahteraan masyarakat terutama petani.

Sektor pertanian terdiri dari subsektor tanaman pangan, subsector hortikultura, subsektor kehutanan, subsektor perkebunan, subsektor peternakan,dan subsektor perikanan.Subsektor hortikultura terdiri dari komoditas buah-buahan, sayuran, tanaman hias, dan tanaman obat-obatan yang sangat potensial untuk dikembangkan sebagai salah satu sumber pendapatan nasional di masa depan.

Indonesia merupakan negara tropis yang kaya akan buah-buahan. Dari sekian banyaknya varietas buah-buahan yang berkembang di Indonesia, tentunya tidak semua dapat diunggulkan. Durian merupakan salah satu varietas buah yang telah diuji dan dipastikan serta dilepas dengan Surat Keputusan Menteri Pertanian Nomor476/KPTS/Um/8/1977 sebagai buah varietas unggul di Indonesia ${ }^{1 .}$

Durian sering dikenal dengan sebutan "raja dari segala buah" (King of Fruit), dan durian adalah buah yang kontroversial. Meskipun banyak yang menyukainya, sebagian orang lain tidak suka dengan aromanya. Durian berasal dari Asia Tenggara, terutama Malaysia dan Indonesia. Disebut durian karena seluruh kulitnya keras dan berlekuk-lekuk taje menyerupai duri ${ }^{2}$. 
Durian Indonesia yang banyak dicari oleh sebagian besar masyarakat Indonesia yang cinta durian diketahui mempunyai aroma yang tajam. Dengan aroma tajam tersebut, masyarakat Indonesia merindukan durian untuk selalu dijadikan pusat konsumsi. Tampaknya aroma tersebut juga menjadi pemicu masyarakat untuk selalu memakan buah durian dalam jumlah yang sangat banyak. Disinilah letak awal mula mitos durian yang dapat mengakibatkan timbulnya beberapa penyakit pada penikmatnya ${ }^{3}$.

Berdasarkan data Badan Pusat Statistik (BPS) tahun 2014, produksi buah durian terbanyak menurut provinsi per tahun adalah Provinsi Sumatera Utara dengan jumlah produksi 128.803 ton, diikuti Provinsi Jawa Barat, Provinsi Jawa Timur dan Provinsi Jawa Tengah masing-masing dengan jumlah produksi 91.097 ton, 91.078 ton dan 65.019 ton, sementara total produksi buah durian di Indonesia adalah 682.323 ton. Dalam hal ini dapat disimpulkan bahwa sebagai daerah yang banyak memproduksi buah durian, berarti banyak pula sampah biji dan kulit durian yang dihasilkan.

Pengembangan tanaman durian di suatu daerah mempunyai harapan besar dalam rangka meningkatkan perekonomian masyarakat pedesaan, karena tanaman durian dapat tumbuh dan berproduksi dengan baik. Oleh sebab itu perlu didukung dengan penelitian. Tanaman durian tumbuh dan berbuah baik didataran rendah hingga ketinggian $800 \mathrm{~m}$ dpl dengan tipe iklim basah. Curah hujan sekitar 1.500-2.500 mm/tahun dan merata sepanjang tahun.lokasi penanamannya terbuka, walaupun relative tahan naungan ${ }^{2}$.

Kebutuhan buah durian yang setiap musim semakin meningkat karena buah durian selain dapat dikonsumsi dalam bentuk segar juga dalam bentuk olahan. Dengan pengembangan tanaman durian maka banyak pihak yang melakukan perbanyakan tanaman buah durian atau dapat disebut pembibitan. Salah satunya di Kecamatan Tanjung Morawa yang sebagian besar penduduknya melakukan pembibitan tanaman durian.

Maka dari itu peneliti merasa perlu diadakan penelitian tentang analisis kelayakan usaha pembibitan tanaman durian untuk melihat kelayakan dari usaha tersebut sehingga dapat menjadi bahan informasi baik bagi petani pembibitan tanaman durian, instansi terkait maupun lembaga yang mendukung usaha ekonomi kerakyatan sehingga usaha ekonomi ini berkembang lebih pesat lagi.

\section{Perumusan Masalah}

Berdasarkan pernyataan yang diuraikan di atas, penulis merumuskan beberapa permasalahan sabagai arah terhadap penelitian yang dilakukan. Adapun permasalahan yang dikemukakan dalam penelitian ini adalah :

1. Berapa besar pendapatan usaha pembibitan durian?

2. Bagaimana kelayakan usaha pembibitan durian?

\section{Tujuan penelitian}

1. Untuk mengetahui seberapa besar pendapatan usaha pembibitan durian

2. Untuk mengetahui kelayakan usaha pembibitan durian

\section{Kegunaan penelitian}

1. Sebagai bahan masukan bagi stakeholder dalam pengembangkan usahasa pembibitan durian

2. Sebagai bahan infomasi ilmiah bagi pihak- pihak yang membutuhkan

3. Bagi penulis sebagai salah satu syarat untuk melakukan penelitian.

\section{B. METODE PENELITIAN}

\section{Metode Penelitian}

Metode penelitian yang digunakan adalah studi kasus (study case). Dalam studi kasus, penelitian yang akan diteliti lebih terarah atau pada sifat tertentu dan tidak berlaku umum, metode yang menjelaskan jenis penelitian mengenai suatu objek tertentu selama kurun waktu tertentu, atau suatu fenomena yang ditentukan pada suatu tempat yang belum tentu sama dengan daerah lain.

Metode Penentuan Lokasi

Penelitian ini dilakukan di Kecamatan Tanjung Morawa Kabupaten Deli Serdang dengan para petani pembibitan durian sebagai populasi penelitian. Metode pengambilan lokasi tersebut adalah dengan cara purposive, yaitu Kecamatan Tanjung Morawa, dengan alasan karena daerah ini merupakan salah satu tempat yang potensial bagi pengembangan pembibitan durian. Penelitian akan dilakukan pada tahun 2015.

Metode Penarikan Sampel

Dalam penelitian ini populasi penelitian adalah para petani pembibitan durian di Kecamatan Tanjung Morawa. Dan untuk penelitian ini diambil sampel sebanyak 12 orang responden petani pembibitan durian dengan menggunakan metode sensus yaitu teknik penentuan sampel dimana semua anggota populasi digunakan sebagai sampel ${ }^{4}$. 
Metode Pengumpulan Data

1. Data Primer

Dalam penelitian ini, pengumpulan data dilakukan den menggunakan metode peneli survey sehingga metode utama pengumpulan data dari responden dilakukan dengan teknik wawancara langsung dengan menggunakan daftar pertanyaan atau kuisioner. Wawancara dilakukan terhadap 12 responden yang dianggap sudah mewakili petani pembibitan yang berdomisili di Kecamatan Tanjung Morawa.

2. Data Sekunder

Pengumpulan data sekunder yang dilakukan dalam penelitian ini adalah dari kepustakaan, isntansi terkait atau lembaga pemerintah yang mempunyai kaitan dengan usaha pembibitan.

Metode Analisis Data

Rumusan masalah yang pertama (1) dianalisis dengan menggunakan metode tabulasi sederhana, yaitu menggunakan rumus analisis pendapatan berdasarkan ${ }^{5}$.

yaitu :

Keterangan :

$$
\text { Pd = TR- TC }
$$

Pd : Pendapatan

TR : Total penerimaan

TC : Total biaya produksi

Rumusan masalah yang kedua (2) dapat dianalisis dengan menggunakan metode analisis :

1. Return Cost Ratio (Rasio R/C)

Dikenal dengan perbandingan antara penerimaan dengan biaya, yaitu untuk menganalisis usaha pembibitan durian di daerah penelitian, secara sistematis dapat dituliskan :

$$
\mathbf{a}=\mathbf{R} / \mathbf{C}
$$

Keterangan :

$$
\begin{array}{ll}
\mathrm{R} & =\text { Penerimaan }(\mathrm{Rp}) \\
\mathrm{C} & =\text { Biaya }(\mathrm{Rp})
\end{array}
$$

Jika $\mathrm{R} / \mathrm{C}>1$ maka usaha pembibitan durian layak diusahakan

Jika $\mathrm{R} / \mathrm{C}=1$ maka usaha pembibitan durian berada di titik impas

Jika $\mathrm{R} / \mathrm{C}<1$ maka usaha pembibitan durian tidak layak dusahakan

2. Benefit Cost Ratio (B/C)

$$
\mathbf{b}=\mathbf{B} / \mathbf{C}
$$

Dimana: $\boldsymbol{B}=$ Pendapatan (Benefit)

$$
\boldsymbol{C}=\text { Biaya }(\text { Cost })
$$

Dimana: Bila $B / C>1$, maka usaha layak untuk diusahakan

Bila $B / C<1$, maka usaha tidak layak untuk diusahakan
Bila $B / C=1$, maka usah impas/BEP (Break Event Point)

Rumusan masalah ketiga (3) dianalisis dengan menggunakan metode analisis deskriptif, yaitu untuk mengetahui masalah dan upaya mengatasi masalah dalam usaha pembibitan durian.

\section{HASIL DAN PEMBAHASAN Analisis Usaha Pembibitan Durian Pendapatan}

Pada dasarnya pendapatan dan penerimaan suatu usaha pembibitan durian ini sangat tergantung pada peranan petani dalam mengelola usaha pembibitannya. Pendapatan petani adalah selisih antara hasil penjualan (produksi) bibit durian dengan total biaya yang dikeluarkan oleh petani. Dari hasil penelitian yang dilakukan di lapangan diketahui bahwa pendapatan yang diperoleh setiap petani adalah berbeda satu sama lainnya. Hal ini disebabkan karena produksi (penjualan), biaya produksi, penerimaan dan pendapatan yang diterima berbeda.

Berikut ini hasil rata-rata produksi (penjualan), biaya produksi, penerimaan dan pendapatan petani pembibitan durian.

Tabel 8. Produksi (Penjualan), Biaya Produksi, Penerimaan dan Pendapatan Petani pembibitan durian / Musim.

\begin{tabular}{clr}
\hline No & \multicolumn{1}{c}{ Uraian } & Rata-Rata \\
\hline 1 & Produksi pembibitan & 5.375 \\
2 & $\begin{array}{l}\text { durian (bibit/Ha) } \\
\text { Harga Jual Bibit Durian }\end{array}$ & 7.500 \\
& $\begin{array}{l}\text { (Rp/Bibit) } \\
3\end{array}$ & $\begin{array}{l}\text { Penerimaan Bibit Durian } \\
\text { (Rp) }\end{array}$ \\
& Total Biaya Produksi & 17.792 .884 \\
& (Rp) & \\
\multicolumn{2}{l}{ Sumber : Data Primer Diolah, 2015 }
\end{tabular}

Berdasarkan Tabel 8 diketahui bahwa produksi (penjualan) yang dihasilkan oleh petani pembibitan durian berbeda-beda, hal ini dipengaruhi oleh banyaknya bibit yang ditanam oleh petani serta harga jual pada masing-masing bibit tersebut, dengan demikian rata-rata produksi (penjualan) untuk bibit durian adalah 5.375 bibit/Ha dengan rata-rata harga jual Rp.7.500/bibit dan menghasilkan penerimaan Rp. 40.312.500.

Dari penerimaan pembibitan durian, maka diperoleh penerimaan. Total penerimaan merupakan keseluruhan yang diterima oleh petani pembibitan durian dari hasil membudidayakan, sehingga rata-rata penerimaan yang diperoleh pada setiap masingmasing petani pembibitan durian yaitu sebernr Rp. 40.312.500 dengan mengeluarkan bi: 
produksi rata-rata sebesar Rp. 17.792.884 untuk mencari pendapatan dapat digunakan rumus :

Pd $=$ TR - TC

$=$ Rp. 40.312.500 -17.729 .884$

= Rp. 22.582.616

Dari perhitungan diatas, maka dapat disimpulkan bahwa petani pembibitan durian memperoleh pendapatan rata-rata sebesar $\mathrm{Rp}$. 22.582.616

\section{Pengujian Kelayakan Usaha}

Untuk mengetahui kelayakan usaha pembibitan durian di daerah penelitian, dapat dilakukan pengujian dengan rumus analisis $\mathrm{R} / \mathrm{C}$ Ratio :

$$
\mathrm{R} / \mathrm{C}=\frac{\text { Total Penerimaan }}{\text { Total Biaya }}
$$

Dengan Kriteria :

Jika R/C > 1 maka usaha pembiitan durian layak diusahakan

Jika $\mathrm{R} / \mathrm{C}=1$ maka usaha pembibitan durian berada di titik impas

Jika $\mathrm{R} / \mathrm{C}<1$ maka usaha pembibitan durian tidak layak dusahakan

$$
\begin{aligned}
& R / C=\frac{\text { Rp.40.312.500 }}{\text { Rp.17.729.884 }} \\
& =2,3
\end{aligned}
$$

Dari perhitungan di atas dapat diartikan bahwa setiap pengeluaran biaya Rp. 1,00 maka akan diperoleh hasil penjualan sebesar Rp. 2,3. Dan dapat dilihat nilai R/C 2,3>1 maka dapat disimpulkan usaha pembibitan durian yang ada di daerah penelitian dikatakan layak untuk diusahakan. Untuk itu produksi bibit durian ini dapat ditingkatkan. Dengan produksi yang semakin tinggi, maka pendapatan petani pembibitan durian juga akan meningkat.

\section{Benefit Cost Ratio (B/C)}

Untuk mengetahui kelayakan usaha pembibitan durian di daerah penelitian, dapat dilakukan pengujian dengan rumus analisis $\mathrm{B} / \mathrm{C}$ Ratio :

$$
\mathrm{B} / \mathrm{C}=\frac{\text { Total Pendapatan }}{\text { Total Biaya }}
$$

Dengan Kriteria :

Jika B/C > 1 maka usaha pembiitan durian layak diusahakan

Jika $\mathrm{B} / \mathrm{C}=1$ maka usaha pembibitan durian berada di titik impas

Jika $\mathrm{B} / \mathrm{C}<1$ maka usaha pembibitan durian tidak layak dusahakan

$$
\begin{aligned}
B / C & =\frac{\text { Rp. 22.582.616 }}{\text { Rp.17.729.884 }} \\
= & 1,3
\end{aligned}
$$

Dapat dilihat nilai $\mathrm{B} / \mathrm{C}$ merupakan perbandingan keuntungan dengan total biaya dimana didapat nilai $\mathrm{B} / \mathrm{C} 1,3>1$ maka dapat disimpulkan usaha pembibitan durian yang ada di daerah penelitian dikatakan layak untuk diusahakan atau menguntungkan.

\section{KESIMPULAN DAN SARAN Kesimpulan}

1. Penerimaan usaha pembibitan durian di Kecamatan Tanjung Morawa yaitu sebesar Rp. 40.312.500 dengan total biaya produksi Rp. 17.639.606 sehingga diperoleh pendapatan sebesar Rp. 22.672.894 per musim panen.

2. Nilai $\mathrm{R} / \mathrm{C} 2,3>1$. Dilihat dari analisis B/C bahwa Penerimaan B/C 1,3>1, maka usaha pembibtan durian di Kecamatan Tanjung Morawa sudah layak untuk diusahakan.

Saran

1. Petani pembibitan durian harus lebih banyak mempelajari tentang cara pembibitan yang baik, dimana petani dapat menyesuaikan jenis bibit yang akan dibudidayakan dan banyaknya bibit yang akan ditebar dengan luas lahan yang dimiliki oleh petani sehingga dapat meningkatkan produksi.

2. Petani seharusnya dapat memanfaatkan lahan yang terbatas dengan menghasilkan bibit yang maksimal.

\section{Daftar Pustaka}

${ }^{1}$ Nuswamarhaeni, 1999. Mengenal buah ung Indonesia. Penebar swadaya. Jakarta

${ }^{2}$ Sunarjono, H. 2013. Berkebun 21 jeni tanaman buah. Penebar swadaya. Jakarta.

${ }^{3}$ Rukmana, R. 1996. Durian. Budidaya dan pasca panen. Konisius. Yogyakarta.

${ }^{4}$ Sugiyono, 2008. Metode Penelitian Bisnis. Alfabeta. Bandung

${ }^{5}$ Mosher, AT. 1981. Membangun Dan Menggerakkan Pertanian. Yasaguna. Jakarta. 